\title{
Intersectionality as a Framework for Understanding Adolescent Vulnerabilities in Low and Middle Income Countries: Expanding Our Commitment to Leave No One Behind
}

\section{Sarah Baird ${ }^{1}$ - Laura Camfield ${ }^{2}$. Anita Ghimire ${ }^{3}$. Bassam Abu Hamad ${ }^{4}$. Nicola Jones ${ }^{5} \cdot$ Kate Pincock $^{6} \cdot$ Tassew Woldehanna $^{7}$}

Accepted: 4 August 2021 / Published online: 1 September 2021

(c) The Author(s) 2021

\begin{abstract}
Given increasing policy attention to the consequences of youth marginalisation for development processes, engaging with the experiences of socially marginalised adolescents in low- and middle-income countries (including those who are out of school, refugees, married, with disabilities or adolescent parents) is a pressing priority. To understand how these disadvantages - and adolescents' abilities to respond to them-intersect to shape opportunities and outcomes, this Special Issue draws on the Gender and Adolescence: Global Evidence conceptual framework which accounts for gender roles and norms, family, community and political economy contexts in shaping adolescents' capabilities. Implicitly critiquing a focus within youth studies on individual agency, the articles advance our understanding of how adolescents' marginalisation is shaped by their experiences, social identities and the contexts in which they are growing up. An analytical framework foregrounding intersectionality and collective capabilities offers a means to politicise these findings and challenge uncritical academic celebration of individual agency as the means to address structural problems.
\end{abstract}

Authors are listed alphabetically to reflect a collective effort as co-editors of this Special Issue.

Nicola Jones

n.jones@odi.org.uk

1 George Washington University, Washington, USA

2 University of East Anglia, Norwich, USA

3 Nepal Institute for Social and Environmental Research (NISER), Kathmandhu, Nepal

4 Al Quds University, Gaza, State of Palestine

5 Overseas Development Institute, London, UK

6 Gender and Adolescence: Global Evidence, London, UK

7 Addis Ababa University, Addis Ababa, Ethiopia 
Keywords Adolescence · Gender - Sustainable Development Goals · Capabilities · Marginalisation $\cdot$ Child marriage $\cdot$ Refugees $\cdot$ LMICs

\section{Résumé}

Cet article présente l'objet de ce numéro spécial : le programme Ne Laisser Personne Pour Compte (en anglais: Leave No One Behind ou LNOB) qui sous-tend les Objectifs de développement durable à l'horizon 2030 et sa relation avec les expériences des adolescentes et des adolescents dans les pays du Sud. Nous soutenons que l'agenda LNOB souligne l'importance d'explorer les réalités vécues des adolescent.es particulièrement marginalisé es dans les pays à revenu faible et intermédiaire (PRFI), y compris les adolescent·es handicapé·es, les adolescent·es réfugié·es, les adolescent·es non scolarisé·es, les adolescentes déjà mariées et les mères adolescentes. Pour comprendre la façon dont ces désavantages - et la capacité des adolescent.es à y répondre - se recoupent, les articles de ce numéro spécial s'appuient sur le cadre conceptual du programme Gender and Adolescence: Global Evidence (Genre et Adolescence: des données probantes mondiales ou GAGE). Ce cadre tient compte des rôles et des normes de genre, du contexte et de la capacité individuelle d'agir dans le façonnement des capacités des adolescent.es. Quatre domaines de capacités spécifiques sont au centre des articles : le bien-être psychosocial, l'intégrité corporelle, la capacité de faire entendre sa voix, la capacité d'agir par et pour soi-même, et l'éducation et l'apprentissage. En fin de compte, ce numéro spécial vient exposer les défis et les opportunités qui se présentent aux adolescent-es marginalisées dans les PRFI et explore les politiques qui permettent de garantir que personne ne soit « laissé·e pour compte $\gg$.

\section{Introduction}

Across lower- and middle-income countries (LMICs), young people's outnumbering of other demographics represents both an opportunity and a threat (Sommers 2011; Bersaglio et al. 2015). The second decade of life is a time when young people become sexually active, exit education and enter work (Patton et al. 2016), making this an important window of opportunity for interventions. Yet, Sukarieh and Tannock (2008) argue that the use of 'youth' as a construct within policy, development, media and public debates and conflict requires more critical interrogation as there is too often an instrumentalist focus (e.g. harnessing youth for national economic growth) at the expense of youth rights (e.g. to decent work) and the services and the support they require to realise these. Indeed, a growing body of work is increasingly making explicit the connection between the disenfranchisement and limited employment and education opportunities for young people, and ongoing economic restructuring processes and political instability (Mains, 2012). Detailed research across multiple contexts in the global South explores the consequences of these policies for the extreme inequalities in opportunities and outcomes of youth around the world as well as emphasising the agency of young people in navigating these conditions (Jeffrey 2012; Honwana 2012, 2019; Abebe 2020). 
The 2015 Sustainable Development Goals (SDGs) have for some practitioners represented a significant shift away from historically instrumental framings of youth within development policy. The focus of the SDGs and associated indicators is on tackling inequality and injustice rooted in existing political, economic and social power structures. The inequalities that limit opportunities for young people have been identified as a key focus of this post-2015 development agenda (UN Secretary General 2014; Bersaglio et al. 2015). Importantly, the SDG Agenda recognises that segments of the population that are typically excluded from meaningful participation in decision-making and economic development are those which are already left behind in terms of material well-being, education, health and other basic services (Samman, 2017; Renner et al 2018).

Where the preceding Millennium Development Goals' use of national averages and focus on economic measures to assess poverty rates had served to hide pockets of inequality from view, the SDGs seek to disaggregate these data and target those who are missing out on national progress (Pogge and Sengupta, 2016; Freistein and Mahlert, 2016). It is one function of this Special Issue to address the continued dearth of gender- and age-disaggregated data on adolescence necessary to inform tailored and inclusive policy and programming.

Beyond gender and age disaggregation, a tendency remains within international development to eschew theorisation of how disadvantage operates in practice, focussing rather on often narrow, technocratic understandings of what works (Unterhalter et al 2012). This can mean that the implications of context and complexity for putting ideas into practice remains inadequately examined. The task of this Special Issue is therefore to also engage with this complexity in the context of work with adolescents. By adapting a collective capabilities and intersectional analysis lens, the authors highlight how the most marginalised girls and boys in diverse lower- and middle-income countries experience and navigate disadvantage that is structurally embedded, including within processes of development itself.

\section{Gender and Adolescence}

As young people move through adolescence, gender becomes a significant factor in their trajectories, often setting a path that will dictate their opportunities in adulthood. Adolescence is a period when restrictive social norms inhibit opportunities for girls in LMICs. With puberty, gender norms begin to confine girls' lives (Basu and Acharya 2016; McCarthy et al. 2016). Restrictions on girls' agency and mobility as a result of norms about appropriate feminine behaviour (Cresswell and Uteng 2008; Porter 2011; Calder et al. 2018) can result in further marginalisation in adulthood (Ampofo 2001; Bhana 2015). This is also because the physical developments associated with puberty mean girls are increasingly seen as sexual subjects rather than children. Although there is considerable heterogeneity across contexts, girls in lower-income countries also have less access to social and economic resources such as peer networks and opportunities for paid employment, restricting the options available to them (Steinberg and Monahan 2007; Patton et al. 2009; Diers 2013). They are also less likely than boys to be included in family decision-making, even in decisions that are directly related to their own lives 
such as how they spend their time, who they marry and how long to continue education (Young 2009).

Gendered vulnerability is not specific to women and girls. As noted in much of the literature on youth transitions, boys experience distinct forms of gender-based vulnerability during adolescence, due to norms about financially supporting their families, regardless of the quality of work available. Boys in lower-income countries are more likely to enter school late, repeat grades and in some contexts may leave earlier than girls due to paid labour pressures (UNESCO Institute of Statistics 2018; UNESCO 2018). While girls face higher rates of sexual violence, boys are frequently at greater risk of other types of physical violence such as bullying and corporal punishment both as survivors and perpetrators (Pinheiro 2006). They are also at significantly greater risk of suicide and substance abuse, reflecting gendered expectations that boys should not express emotions or seek help (WHO 2002; McKinnon et al. 2016).

\section{Marginalised Adolescents in a Global Context}

The evidence base also shows that certain groups of adolescents face particular challenges and are at a heightened risk of exclusion within broader processes of development; these groups also make up significant numbers of the overall global youth cohort. This special issue pays particular attention to four groups: refugees and other displaced youth; married adolescents and adolescent mothers; adolescents with disabilities; and adolescents who are out of school and/or working.

\section{Adolescent Refugees and Internally Displaced Persons}

There are an estimated 25 million refugees and more than 40 million internally displaced persons globally, of whom over half are under the age of 18 (UNHCR 2018). In the contexts of insecurity and social upheaval, adolescents face overlapping challenges that require tailored policies and programming (UNESCO 2019). Their educational trajectories are interrupted by displacement (Ferris and Winthrop 2010; Wanjiru 2018), while high poverty rates can force many to leave school to find work (Evans and Lo Forte 2013). Adolescent girls in refugee and IDP communities are at greater risk of sexual and gender-based violence (Asgary et al. 2013; IRC 2016). They often experience further restrictions on their agency and mobility due to family fears about the dangers of camps or host communities (DeJong et al. 2017). This in turn amplifies the social isolation displaced adolescents experience in new places, where they feel like outsiders and do not know how long they will stay (Jabbar and Zaza 2014; Hassan et al. 2016). Adolescent refugees also have high rates of post-traumatic stress disorder (PTSD) and anxiety (Kolltveit et al. 2012).

\section{Adolescent Mothers and Married Adolescents}

Eliminating child marriage has become an international objective under SDG 5's broader goal of empowering girls and women, which has prompted more research to 
understand risk factors and consequences. Yet, one in five girls globally still marry before the age of 18, making it unlikely that the 2030 target will be met (Misunas et al. 2019). The negative consequences of child marriage include early pregnancy, poorer health and psychosocial well-being outcomes, increased rates of school dropout, less agency within household decision-making and heightened risk of domestic violence (Parsons et al. 2015; Presler-Marshall et al. 2020). Progress in this area is difficult to sustain; for example, due to displacement and changing patterns of poverty and inheritance, traditional strategies to combat child marriage are no longer as effective (Jones et al. 2020). Already-married girls and adolescent mothers are particularly marginalised, with research and programming often treating them as 'already lost' (Siddiqi and Greene 2019). And while the absolute numbers are much lower, there is also an emerging focus on the particular vulnerabilities of adolescent boys who marry as children (Gastón et al. 2019).

\section{Adolescents with Disabilities}

In LMICs, adolescents with disabilities face multiple and interlinked challenges in realising their rights to education, health, recreation and general well-being due to stigma, discrimination, and lack of provision and/or access to appropriate care (WHO 2018; Jones et al. 2018). The SDGs have brought increased attention to how disability intersects with socioeconomic marginalisation (Kuper et al. 2019), yet much of the research in this area does not address adolescents' experiences. Adolescents with disabilities report significantly more social and emotional problems than their peers (Mekonnen et al. 2015). Disability also intersects with other inequalities linked to gender and displacement; adolescent girls with disabilities face multiple challenges around mobility, participation and agency (Manning et al. 2016). Refugees are more likely (in some contexts) to have conflict-induced disabilities, while also lacking appropriate services and support (Presler-Marshall et al. 2019). Compounding their marginalisation is the fact that adolescents with disabilities are often not consulted about their experiences, with research not usually adapted to enable them to participate (Kembhavi and Wirz 2009).

\section{Out-of-School and Working Adolescents}

SDG 4 emphasises the importance of education as a means to improve young people's trajectories, building on the successes of the MDGs in expanding primary enrolment. Yet, gains in primary schooling for girls all but evaporate at secondary level-especially for those from the poorest households, for whom attrition rates are highest. Even when girls enrol in school, their attendance is often hampered by caring and home responsibilities (Nanda et al. 2014; CSA 2014). Other inequalities such as urban poverty act as obstacles, with children from slum areas often excluded from school altogether (Cameron 2017). Poor-quality teaching, inadequate resourcing and corporal punishment are major factors behind the low completion and literacy rates seen in many LMICs (UNESCO 2015, 2018; Vaughan 2016). School attrition is also linked to the draw of employment, especially for boys, for whom 
gender norms often devalue academic achievement (UNESCO 2015). Yet, the work available is often poorly paid, dangerous and exploitative, exacerbating the intergenerational transmission of poverty (ILO 2017).

\section{The GAGE Conceptual Framework}

The articles in this Special Issue draw on findings from research undertaken as part of the Gender and Adolescence: Global Evidence (GAGE) programme, a longitudinal cross-country research project to understand the lives of adolescents in six LMICs running from 2015 to 2024. The papers included in this Special Issue focus on baseline findings from ongoing research. A number of interconnected theories and concepts inform the conceptual framework, shown in Fig. 1, that unites these articles.

The 'new social studies of childhood' (Prout and James 1990; Hendrick 1997) draws on the United Nations Convention on the Rights of the Child to emphasise young people's social connectedness, autonomy and participation in issues that affect them. This challenges the tendency within development interventions to frame younger people as passive recipients (White and Choudhury 2007), instead seeing the relational and evolving nature of young people's agency and capacities (Lansdown 2005). Exploring adolescents' experiences entails recognising that they are not only 'children' in need of protection, but also socially connected actors in their own right whose relationship to the world around them is changing, with major consequences for their well-being and adulthood.

Thinking about how to improve adolescents' well-being requires a framework that can account for the dynamics between individuals and society, and the negotiated character of both structure and agency. GAGE's approach is influenced by

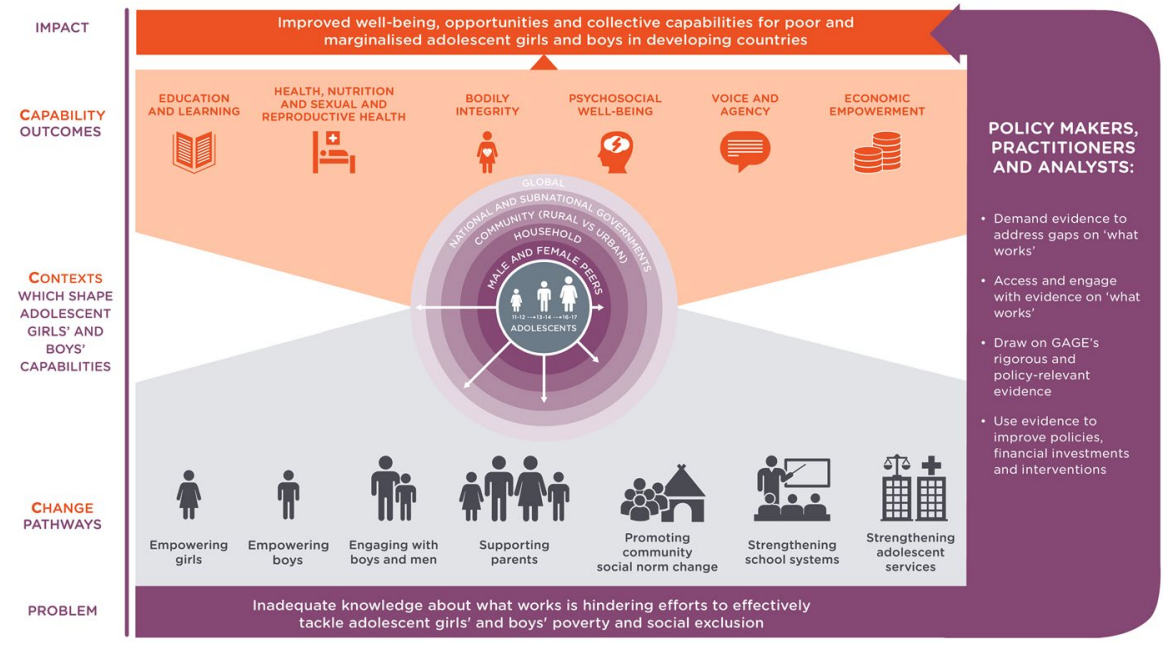

Fig. 1 GAGE 3 'Cs' Conceptual Framework: Capabilities, Contexts and Change Strategies 
Amartya Sen's capabilities framework (1984), and Martha Nussbaum (1997, 2000) and Naila Kabeer's (2003) work to develop a gendered analysis of capability sets. In addition to using economic indicators to measure progress, it emphasises that development interventions should aim to expand freedoms; specifically, the freedom to 'be' and 'do' things that one has reason to value (Sen 1984, 1993, 1999).

Drawing on these ideas, the research in this Special Issue seeks to engage with adolescents as agents in their own lives, whose ability to live and do things in ways that they value is inherently linked to the resources and assets they have access to. Recognising young people's capabilities is fundamental to supporting their aspirations, opportunities and empowerment. Yet, this is not just a matter of individual expansion of capability sets; as the 'new social studies of childhood' suggest, the challenging and complex contexts of poverty, unemployment, conflict and displacement all structure the choices open to adolescents.

A capabilities framework also offers ways to think critically about how to address the intersecting forms of disadvantage that adolescents encounter. Drawing on the work of Black feminist scholars, intersectional theory deepens our understanding of the ways in which different aspects of social identity converge to produce particular experiences of marginalisation (Hooks 1981; Crenshaw 1989; Collins 1990). Overlaps between different marginalised social identities (e.g. being a girl and living in a rural area, or being disabled and a refugee) reinforce and amplify vulnerability. An intersectional lens can enable a nuanced understanding of the marginalisation of particular groups of adolescents across multiple identities.

By engaging with how adolescents' capabilities are shaped by the contexts in which they grow up, this research seeks to situate the emotional and physical changes of adolescence and the specific disadvantages of particular groups within these broader sociocultural, economic and political landscapes (Landsdown 2005; James 2007). This provides both a more nuanced, socially located understanding of age (Clark-Kazak 2009) and helps identify opportunities for changes that will expand the capabilities of adolescents in relation to the particular vulnerabilities they face.

\section{Collective Capabilities}

The notion of 'collective capabilities' seeks to address what some critics have argued is an over-emphasis on individuals within the approach, with insufficient attention to the factors that shape people's ability to overcome group-based marginalisation (Stewart and Deneulin 2002; Stewart 2005; Ibrahim 2006, 2013; Shove 2010; Ibrahim 2017). Collective capabilities accrue not just to individuals or those who are part of the immediate group involved in activities, but to all those marginalised by the norms targeted for change (Ibrahim 2006; Kabeer and Sulaiman 2015). One of the innovations of the framework used by the research in this special issue is the way it addresses a historical lacuna in the capability approach by recognising the power of groups working together towards shared goals of empowerment and capability expansion. 
Adolescent capabilities and the strategies that are pursued to expand them are heavily contingent on a supportive, enabling context. The GAGE conceptual framework encompasses family, community, state, national-level and global contexts. The research in the Special Issue has sought to engage not only with adolescents, but also with their caregivers and families, actors within their communities, service providers, and key institutions such as the justice system, ministries of women and children and labour and social affairs. Understanding how different contexts affect adolescents' capabilities to 'be' and 'do' is an important dimension of the framework, and is something that may be missed by a focus on poverty reduction alone. Prosperity may improve women's basic well-being but intensify other restrictions on their ability to make choices (Kabeer 1999). Key actors in adolescents' lives can support expansion of their capabilities, including male peers. Indeed, evidence suggests that promoting positive masculinities among male peers is key to achieving gender-transformative outcomes for girls (GAGE consortium, 2019).

The research reported in this special issue explores what works in helping adolescents flourish across these capability domains. A collective approach to capabilities underlines the importance of ensuring that policy and programme interventions are nuanced and contextualised and the significant role of structural disadvantage at family, community, national and global levels in shaping adolescents' outcomes is taken into account (Eyben 2013; Green et al. 2013). In recognition of these dynamics, change strategies may be explicitly adolescent-targeted-or entail efforts to reduce poverty, tackle discriminatory gender norms and promote well-being more broadly among families and communities, which can have significant spill-over effects on adolescent girls' and boys' contextual realities. The interplay between individual and structural disadvantages is identified across the articles in the Special Issue, as is the effectiveness of interventions at different, often multiple levels.

\section{Overview of Articles}

This Special Issue focuses on four 'capability domains' within the GAGE conceptual framework that shape adolescents' collective and individual well-being: education and learning; bodily integrity; psychosocial well-being; and voice and agency. Applying an intersectional lens to vulnerability, the articles highlight the gendered experiences of particularly marginalised groups of adolescents across these domains, whose vulnerabilities are compounded by their location at the intersection of gender and other identities, and who are commonly excluded from discussions of development and adolescence. Articles explore context-specific understandings of 'what works' in expanding their capabilities, improving their well-being, and promoting equality and transformative social justice. The country contexts, capability domains and social identities of focal adolescents for each article are shown in Table 1.

The empirical articles draw on data generated using a variety of innovative methods, often in combination. The first article, by Baird et al., frames these articles, showing how GAGE's conceptual framework discussed above informs a methodological approach that unites empirical research across the case study countries. It discusses the methods used, including quantitative surveys with very young 


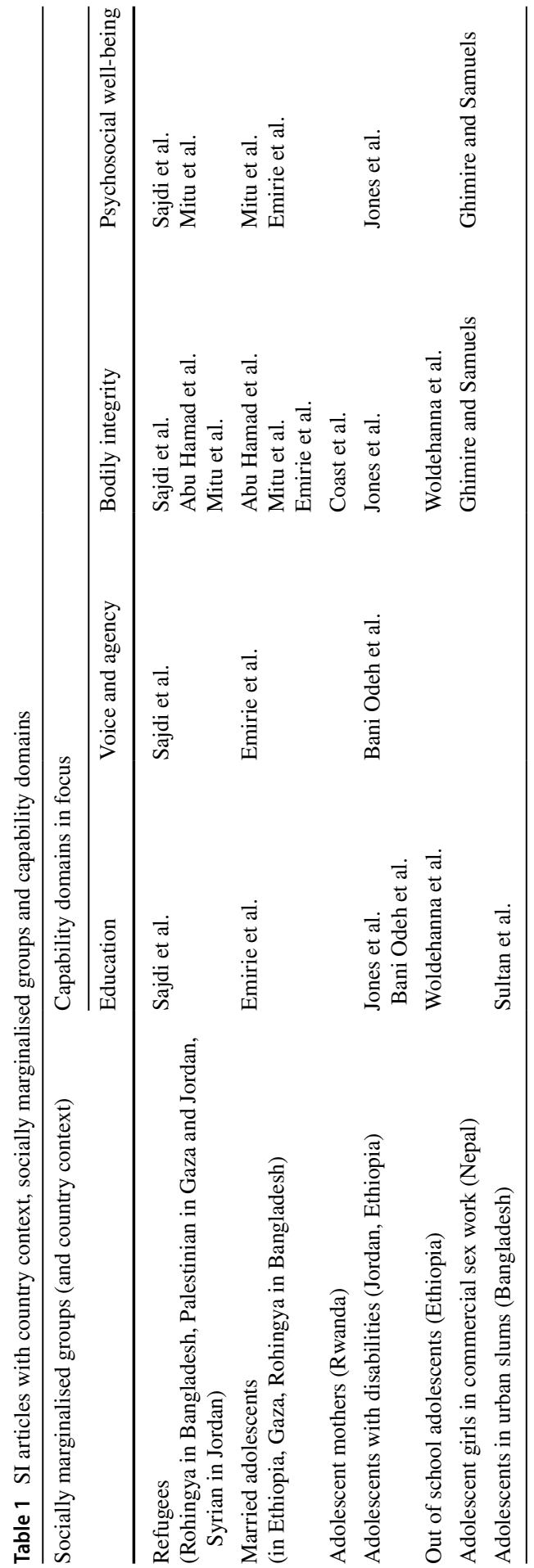


(10-12 years) and older (15-17 years) adolescents and caregivers, qualitative interviews with individuals and groups, and participatory research with marginalised adolescents. Through examples drawn from across the special issue, Baird et al. argue that a longitudinal and mixed-methods approach that incorporates these elements can promote high-quality data and ethical and impactful research processes.

\section{Adolescent Education and Learning}

It is essential that the factors mediating aspirations and access to affordable, ageappropriate, gender-responsive learning are better understood to enable young people to realise their right to education.

In most low-income countries, the secondary education of girls tends to receive less investment and attention from families than their male peers, and the poorest adolescent girls are least likely to attend school regularly and continuously or progress to secondary education (UNESCO 2020). In this issue, Sultan et al. explore the experiences of adolescent girls in the urban slums of mega-city Dhaka, finding that while parents have high aspirations for their children, poor access to quality schooling and norms about caring for siblings and housework mean that many girls cannot continue with their education.

In the contexts of displacement, fears of sexual harassment and exposure to violence are cited as the main reasons for keeping adolescent daughters at home and out of school (Abu Hamad et al. 2017). Sajdi et al.'s article on the gendered experiences of young Syrian refugees living in Azraq camp in Jordan finds that conservative social norms around marriage and the fear of harassment in public spaces around the camp were commonly cited reasons for girls' dropping out of school. They observe the multiple ways that gender norms increasingly restrict adolescent girls' freedoms and opportunities as they age, with older adolescents less likely to be in school than younger girls.

Research also indicates that adolescents with disabilities are less likely to attend school, in anticipation that they will not be able to secure an independent future for themselves (Trani et al. 2011). In Jordan, Bani Odeh et al. observe that low educational aspirations and learning outcomes among adolescents with disabilities are connected to other forms of marginality, such as living in an area where there are few specialised schools or a lack of acceptance of disability by communities. In Ethiopia, Jones et al. point to the role of parental and school support in shaping adolescents' educational opportunities and outcomes; they find that the low attainment of adolescents with disabilities in comparison to their peers is linked to both a lack of inclusive and specialised teaching practices but also to poverty and neglect connected to the devaluing of children with disabilities (Jones et al. 2016a, b).

\section{Adolescent Bodily Integrity}

According to the International Covenant on Civil and Political Rights, "the right of a woman or girl to make autonomous decisions about her own body and reproductive functions is at the very core of her fundamental right to equality and privacy, 
concerning intimate matters of physical and psychological integrity" (UN Working Group on the issue of discrimination against women in law and in practice 2017). In this regard, adolescents need knowledge, skills, support and resources to avoid threats to their bodily integrity, i.e. their right to autonomy and self-determination over their own body, such as child marriage, sexual and gender-based violence, and corporal punishment. Sexual and reproductive health rights are integral to bodily integrity, and enhancing adolescent capabilities in this domain is a complex issue, especially when it comes to engaging families and communities (e.g. Heidari 2015).

Parents and teachers alike often enforce discipline through violent punishment, with boys more likely to be physically punished than girls and more vulnerable to bullying (Hoeffler 2017). In Ethiopia, Woldehanna et al. use quantitative analysis to look at out-of-school adolescents' aspirations and their psychosocial well-being, showing that violence, both at home and school, increases school dropout because it makes adolescents fearful and leads them to struggle with concentration in class. The authors observe that boys are much more likely to experience violence from peers and teachers than girls.

Girls meanwhile are at greater risk of psychological, sexualised and economic violence than their male peers (UNICEF 2014a). Yet, frequently this is normalised or hidden, especially for those who are already the most marginalised, which perpetuates cyclical and intergenerational disadvantage. Coast et al. use mixed methods to explore the experiences of adolescent mothers under the age of 18 in Rwanda, looking at the role of gender norms and poverty in explaining higher rates of adolescent pregnancy in rural areas. They find that processes of social exclusion mean that having children as an adolescent has both economic drivers and consequences, compounded by poor access to reproductive health services due to stigma and social norms about age-appropriate sexuality.

In other contexts, parents may view marriage as a way to protect their daughters from sexual violence and reduce economic pressure on their households (Tefera et al. 2013; ICRW 2016), especially in the contexts of displacement. Among Syrian refugees in Jordan, for example, rates of child marriage rose from 12 to $32 \%$ in just three years at the height of the conflict (UNICEF 2014b). Abu Hamad et al. in this Special Issue use mixed methods to look at the intersecting vulnerabilities that both drive and result from child marriage among both Gazans and Syrian refugees in Jordan with a particular focus on health and bodily integrity. This article shows that conflict, poverty and social exclusion have increased child marriage among Syrian refugees, whereas among Gazans under protracted displacement, social protection programming and expanding girls' access to secondary education have contributed to the reduction of child marriage.

\section{Adolescent Psychosocial Well-Being}

To ensure psychological well-being, adolescents need to develop a strong and resilient sense of self-esteem; be valued and emotionally supported within their families; have the skills to develop good relationships with their peers and participate in their communities; and access appropriately tailored mental health services. Yet, 
the evidence suggests that adolescents face various challenges achieving these capabilities, and the most socially disadvantaged, including many of the young people that are at the centre of this Special Issue, are often subject to chronic adversity, i.e. exposure to multiple, often overlapping and sustained adverse events (e.g. conflictrelated trauma, displacement, economic hardship, family breakdown) which trigger what Nelson et al. (2020) term a 'toxic stress response'.

Overall, adolescent girls have less free time to play and explore with peers and develop independent identities outside home and school than boys (WHO 2014). Families' fears about girls' safety can lead them to restrict girls' mobility, increasing their sense of isolation (Hamad et al. 2018). The psychosocial needs of adolescent girls in conflict-affected areas and contexts of displacement are particularly acute, as danger further prevents girls interacting with peers in adolescent-friendly, safe spaces (Robles and Spindler 2016; Falb et al. 2016). Mitu et al.'s mixed-methods paper in this Special Issue focuses on the experiences of married Rohingya refugee girls in Cox's Bazar, Bangladesh, where child marriage-driven by safety concerns, economic strain and cultural norms-has had harmful effects on girls, including social isolation and risks to their bodily integrity. The authors use their evidence base around the participation of women in livelihoods training to recommend developing economic opportunities for adolescent girls and young women, as well as improving social protection and undertaking awareness-raising programming with parents, community and religious leaders.

The article by Ghimire and Samuels in this issue on migration for commercial sex work (CSW) in Nepal also highlights the role of both the local socioeconomic context in shaping the opportunities available to adolescent girls, but focuses on the possibilities for sex work outside of traditional venues that have been enabled by access to the internet. The authors find that these changes leave adolescent girls involved in the sector more vulnerable and isolated, creating new challenges for programmatic interventions that focus on traditional sex work venues.

Disability also places adolescents at risk of poor psychosocial outcomes because of its connection to social marginalisation, as found by Bani Odeh et al. in Jordan and by Jones et al. in Ethiopia, both in this Special Issue. These articles explore the ways that major structural challenges, including a lack of accessible, disabilityinclusive schooling; discriminatory attitudes within families and communities; lead to higher rates of social exclusion and poor mental health for adolescents with disabilities compared to their non-disabled peers.

\section{Adolescent Voice and Agency}

Adolescent voice and agency encompasses young people's mobility, ability to express their views and to be listened to within the home, school and community, and to have a say in major life decisions, including relating to schooling, work and marriage (GAGE Consortium 2019; Jones et al. 2020). Adolescents' voice and agency can be strengthened by enabling appropriate access to information technologies, and inviting their participation in decision-making at home, in school and in the community. In this Special Issue, for example, Woldehanna et al. find that in 
Ethiopia, it is the agency of adolescents-measured in terms of their say in household decisions - that enables them to remain in school even when they experience violence from teachers, peers and at home.

The voice and agency of girls is particularly constrained due to gender norms about how, when and in what contexts girls are free to express themselves. Articles in this Special Issue emphasise that nonetheless, girls find ways to exercise some degree of agency. Emirie et al. draw on qualitative research to look at the prevalence and causes of child marriage in two rural areas of Ethiopia, showing how discriminatory social norms and economic factors affect girls and boys differently. The authors introduce nuance into the debate by showing that in some contexts, in the absence of alternative adulthood pathways and a dearth of role models, younger adolescents themselves are pushing to marry against their family's wishes.

Sajdi et al.'s article underlines the importance of the structural context for shaping opportunities for voice and agency. Their findings in Jordan highlight the multiple and intersecting disadvantages and vulnerabilities that adolescents experience as a result of displacement and their implications for voice and agency, particularly for girls, which are restricted by strong surveillance and security measures, the remote desert location, and their limited mobility and income-generating opportunities.

For adolescent girls and adolescents with disabilities, voice and agency are particularly constrained. Adolescents with disabilities often have no say even in basic decisions about their lives (Trani et al. 2011). Both adolescent girls and adolescents with disabilities also lack role models: in lower-income countries in particular there are few people with disabilities in leadership roles (Watson 2015; Vaughan 2016). Bani Odeh et al.'s article highlights the impact on adolescents with disabilities of living in areas where their participation is not supported or facilitated, underlining the importance of structural investment and support to address marginalisation.

\section{Implications for Policy and Practice}

An important feature of this special issue is the reflection of the authors on how adolescent individual and collective capabilities can be expanded. Against the backdrop of the myriad, complex struggles young populations in LMICs are currently encountering as they transition to adulthood, a number of recent policy changes have showed promise for addressing the challenges highlighted in these articles. The SDGs in particular present an opportunity to rethink the way we understand social and economic progress and to frame policies and programming accordingly (Alkire 2018). Despite these developments, however, gaps in knowledge and conceptual challenges remain, with consequences for how interventions with adolescents are conceptualised and implemented.

First, there is a lack of consistent operationalisation of 'adolescence' within development programming. The UN Convention on the Rights of the Child (UNCRC) defines a child as any person below the age of 18 (UNICEF 1989), but defining older children and young adults is a more complex task. While there are no formal or statutory interpretations, the World Health Organization (WHO) proposes that 'adolescents' are aged 10-19, 'youths' 15-24, while the term 'young people' 
is used to describe those aged 10-24 (WHO 2015). Yet often, there is a 'semantic ambiguity' (Duschinsky and Barker 2013) in how development organisations use these categories. Adolescents and children are often conflated when it comes to 'child protection' work, while adolescent girls may be grouped into a broader category of 'women and girls' within interventions around sexual and reproductive health. However, programmes that fail to engage with adolescence as a unique life stage, or acknowledge the distinction between younger and older adolescence, will not be able to intervene in ways that account for how age and gender mediate access to resources and adolescents' capacity to make decisions about their own lives. By calling attention to the specific experiences of adolescents, this Special Issue contributes to a better understanding for development practitioners of how to more effectively include them in development processes.

Second, failure to target adolescents is amplified by knowledge gaps about adolescents in marginalised communities. This has implications for effective targeting across the board. Targets to measure progress towards the SDGs do not consistently disaggregate by age, gender, disability and refugee status (Guglielmi and Jones 2019). Refugee adolescents are among the most overlooked populations in data collection and programming (Presler-Marshall 2018; Samman et al. 2018) and data on the availability of school-based infrastructure for students with disabilities is practically non-existent (UNICEF 2017). Given that these groups are among the most likely to experience marginalisation (Frederick 2010; Trani et al. 2011; Abu Hamad et al. 2017), these are significant omissions. By centring on the experiences of adolescents whose social identities mean that they are often overlooked, this Special Issue calls attention to the limitations of policies and interventions which fail to recognise diversity in adolescents' experiences, and explores what is necessary to promote their inclusion.

Third, currently policy approaches often fail to conceive of vulnerabilities as intersectional. At present, only $8 \%$ of all SDG targets are gender- and age-disaggregated (Guglielmi and Jones 2019) with even fewer organisations considering the effects on adolescent capabilities of challenges such as displacement, motherhood and disability. As recognised within the GAGE conceptual framework and emphasised within intersectional theory, marginalisation is a political and context-specific experience. Social identities in and of themselves generate vulnerability when social and policy environments are unsupportive because they do not recognise adolescents' rights; they may also produce marginality through unjust norms, laws and institutions. The articles in this Special Issue contribute a more nuanced understanding of how adolescent capabilities may be constrained or enabled through their attention to these dynamics.

\section{Conclusion}

Engaging with adolescents' lived experiences from their own perspectives, in ways that acknowledge the broader contexts of their lives, is key to understand the diverse individual and collective trajectories of adolescents. This includes how they change with age, the specific role of gender roles and norms, and how development 
and humanitarian programming and policies affect them. The papers in this Special Issue build on the scant evidence in this area. Understanding the heterogeneous experiences of adolescents requires a conceptual framework that can grasp how structural inequalities and truncated opportunities for political and economic participation interact with social norms about age and gender to produce exclusion. This understanding can help those working to support young people's well-being and full human capabilities to hone their policy and programming efforts across the spectrum of gender, disability, marriage and sexuality, religious and cultural identity, citizenship status and geographic location. It is our hope that the framework underpinning this Special Issue contributes to this critical endeavour.

Open Access This article is licensed under a Creative Commons Attribution 4.0 International License, which permits use, sharing, adaptation, distribution and reproduction in any medium or format, as long as you give appropriate credit to the original author(s) and the source, provide a link to the Creative Commons licence, and indicate if changes were made. The images or other third party material in this article are included in the article's Creative Commons licence, unless indicated otherwise in a credit line to the material. If material is not included in the article's Creative Commons licence and your intended use is not permitted by statutory regulation or exceeds the permitted use, you will need to obtain permission directly from the copyright holder. To view a copy of this licence, visit http://creativecommons.org/licen ses/by/4.0/.

\section{References}

Abebe, A. 2020. The key challenges of youth in Ethiopia. Journal of Agricultural Economics and Rural Development 6 (1): 684-688.

Alkire, S. 2018. The real wealth of nations. Sustainable Goals. 19th March 2018. www.sustainablegoals. org.uk/real-wealth-nations/

Ampofo, A.A. 2001. 'When men speak women listen': Gender socialisation and young adolescents' attitudes to sexual and reproductive issues. African Journal of Reproductive Health 5 (3): 196-212.

Asgary, R., E. Emery, and M. Wong. 2013. Systematic review of prevention and management strategies for the consequences of gender-based violence in refugee settings. International Health 5 (2): 85-91.

Basu, S., and E. Acharya. 2016. Gendered socialization of very young adolescents: Perceptions and experiences of adolescents and their parents from a disadvantaged urban community of Delhi, India. Paper presented at conference on Adolescence, Youth and Gender: Building Knowledge for Change; 8-9 September, Oxford.

Bersaglio, B., C. Enns, and T. Kepe. 2015. Youth under construction: The United Nations' representations of youth in the global conversation on the post-2015 development agenda. Canadian Journal of Development Studies 36 (1): 57-71.

Bhana, D. 2015. Sex, gender and money in African teenage conceptions of love in HIV contexts. Journal of Youth Studies 18 (1): 1-15.

Cameron, S.J. 2017. Urban inequality, social exclusion and schooling in Dhaka, Bangladesh. Compare: A Journal of Comparative and International Education 47 (4): 580-597.

Calder, R. 2018. Private sector involvement in development: What impact on gender norms? Report. London: ODI.

Clark-Kazak, C. 2009. Towards a working definition and application of social age in international development studies. Journal of Development Studies. 45 (8): 1-18.

Collins, P.H. 1990. Black feminist thought: Knowledge, consciousness and the politics of empowerment. Boston: Unwin Hyman. 
Crenshaw, K. 1989. Demarginalising the intersection of race and sex: a black feminist critique of antidiscrimination doctrine, feminist theory and anti-racist politics. University of Chicago Legal Forum 139: 139-167.

Cresswell, T., and T.P. Uteng. 2008. Gendered mobilities: Towards an holistic understanding. In Gendered mobilities, ed. T.P. Uteng and T. Cresswell, 1-12. Aldershot: Ashgate.

Central Statistical Agency (CSA) (Ethiopia). 2014. Ethiopia Time Use Survey 2013. Addis Ababa, Ethiopia: CSA. www.timeuse.org/sites/ctur/files/public/ctur_report/9414/ethiopian_time_use_survey_ report_2014.pdf.

DeJong, J., F. Sbeity, J. Schlecht, M. Harfouche, R. Yamout, F. Fouad, S. Manohar, and C. Robinson. 2017. Young lives disrupted: Gender and well-being among adolescent Syrian refugees in Lebanon. Conflict and Health 11(S1): art 23.

Diers, J. 2013. Why the world needs to get serious about adolescents: A view from UNICEF. Journal of Research on Adolescence 23 (2): 197-200.

Duschinsky, R., and M. Barker. 2013. Doing the Mobius strip: The politics of the Bailey Review. Sexualities 16 (5-6): 730-742.

Evans, R., and C. Lo Forte. 2013. UNHCR's engagement with displaced youth: A global review. Geneva: UNHCR.

Eyben, R. 2013. Uncovering the politics of 'Evidence' and 'Results'. A framing paper for development practitioners. Brighton: Institute of Development Studies.

Falb, K., S. Tanner, P. Mallinga, N. Rudahindwa, M. Sommer, and L. Stark. 2016. Intergenerational transmission of caregiver gender norms and adolescent girl's well-being and exposure to violence in humanitarian settings. Paper presented at conference on Adolescence, Youth and Gender: Building Knowledge for Change, 8-9 September, Oxford.

Ferris, E., and R. Winthrop, R. 2010. Education and displacement: Assessing conditions for refugees and internally displaced people affected by conflict. Background paper for Global Monitoring Report. Brookings Institute.

Frederick, J. 2010. Sexual abuse and exploitation of boys in South Asia. A review of research findings, legislation, policy and programme responses. Innocenti Working Paper No. 2010-02. Florence: UNICEF Innocenti Research Centre.

Freistein, K., and B. Mahlert. 2016. The potential for tackling inequality in the Sustainable Development Goals. Third World Quarterly 37 (12): 2139-2155.

GAGE Consortium. 2019. Gender and adolescence: Why understanding adolescent capabilities, change strategies and contexts matters. London: Gender and Adolescence: Global Evidence (GAGE).

Gastón, C., C. Misunas, and C. Cappa. 2019. Child marriage among boys: A global overview of available data. Vulnerable Children and Youth Studies 14 (3): 219-228.

Green, D., C. Roche, R. Eyben, S. Dercon, and C. Witty. 2013. The political implications of evidencebased approaches to development. Oxfam blog. www.oxfamblogs.org/fp2p/?p=13344.

Guglielmi, S., and N. Jones. 2019. The invisibility of adolescents within the SDGs. Assessing gaps in gender and age disaggregation to leave no adolescent behind. London: Gender and Adolescence: Global Evidence (GAGE).

Hamad, B.A., N. Jones, F. Samuels, I. Gercama, E. Presler-Marshall, G. Plank, A. Essaid, S. Ebbini, K. Bani Odeh, D. Bazadough, H. Abu Taleb, H. Al Amayreh, and J. Sadji. 2017. A promise of tomorrow: The effects of UNHCR and UNICEF cash assistance on Syrian refugees in Jordan. London: Overseas Development Institute.

Hamad, B.A., I. Gercama, N. Jones, and N. Al Bayoumi. 2018. 'I prefer to stay silent': Exploring opportunities for and challenges to adolescents' psychosocial and mental health in Gaza. London: Gender and Adolescence: Global Evidence.

Hassan, G., P. Ventevogel, H. Jefee-Bahloul, A. Barkil-Oteo, and L. Kirmayer. 2016. Mental health and psychosocial well-being of Syrians affected by armed conflict. Epidemiology and Psychiatric Sciences 25 (2): 129-141.

Heidari, S. 2015. Sexual rights and bodily integrity as human rights. Reproductive Health Matters 23 (46): 1-6. https://doi.org/10.1016/j.rhm.2015.12.001.

Hendrick, H. 1997. Constructions and reconstructions of British childhood: an interpretive survey, 1800 to present. In Constructing and reconstructing childhood, 2nd ed., ed. A. James and A. Prout, 34-62. London: Routledge Falmer.

Hoeffler, A. 2017. Violence against Children: A critical issue for development. European Journal of Development Research. 29 (5): 945-963. 
Honwana, A.M. 2012. The time of youth: Work, social change, and politics in Africa. Sterling: Kumarian Press.

Honwana, A.M. 2019. Youth struggles: From the Arab spring to black lives matter \& beyond. African Studies Review 62 (1): 8-21.

Hooks, B. 1981. Ain't I a woman: Black women and feminism. Boston: South End Press.

Ibrahim, S. 2006. From individual to collective capabilities: The capability approach as a conceptual framework for self-help. Journal of Human Development 7 (3): 397-416.

Ibrahim, S. 2013. Collective capabilities: What are they and why are they important? Maiyateree 22: 4-8.

Ibrahim, S. 2017. How to build collective capabilities: The 3C-model for grassroots-led development. Journal of Human Development and Capabilities 18 (2): 197-222.

International Center for Research on Women (ICRW). 2016. Child Marriage Facts and Figures. Factsheet. Washington, DC: ICRW. www.icrw.org/child-marriage-facts-and-figures.

International Labour Organization (ILO). 2017. Global employment trends for youth 2017. Paths to a better working future. Geneva: International Labour Office.

International Rescue Committee (IRC). 2016. Violence Prevention and Response at the International Rescue Committee. Factsheet. New York: IRC. www.rescue.org/resource/violence-prevention-andresponse-international-rescue-committee.

Jabbar, S., and H. Zaza. 2014. Impact of conflict in Syria on Syrian children at the Zaatari refugee camp in Jordan. Early Child Development and Care 184 (9-10): 1507-1530.

James, A. 2007. Giving voice to children's voices: Practices and problems, pitfalls and potentials. American Anthropologist 109 (2): 261-272.

Jeffrey, C. 2012. Geographies of children and youth II: Global youth agency. Progress in Human Geography 36 (2): 245-253.

Jones, N., E. Presler-Marshall, and M. Stavropoulou. 2018. Adolescents with disabilities: Enhancing resilience and delivering inclusive development. London: Gender and Adolescence: Global Evidence.

Jones, N., E. Presler-Marshall, G. Kassahun, and M. Kebedi. 2020. Constrained choices: Exploring the complexities of adolescent girls' voice and agency in child marriage decisions in Ethiopia. Progress in Development Studies 20 (4): 296-311.

Jones, N., B. Tefera, G. Emirie, B. Gebre, K. Berhanu, E. Presler-Marshall, D. Walker, T. Gupta, and G. Plank. 2016b. One size does not fit all: The patterning and drivers of child marriage in Ethiopia's Hotspot Districts. Briefing Paper. London: UNICEF and ODI.

Jones, N., B. Tefera, E. Presler-Marshall, T. Gupta, G. Emirie, B. Gebre, and K. Berhanu. 2016a. What works to tackle child marriage in Ethiopia. A review of good practice. Briefing paper. London: ODI and UNICEF.

Kabeer, N. 1999. Resources, agency, achievements: Reflections on the measurement of women's empowerment. Development and Change 30: 435-464.

Kabeer, N. 2003. Making rights work for the poor: Nijera Kori and the construction of 'Collective Capabilities' in rural Bangladesh. Working Paper 200. Brighton: IDS.

Kabeer, N., and M. Sulaiman. 2015. Assessing the impact of social mobilization: Nijera Kori and the construction of collective capabilities in Rural Bangladesh. Journal of Human Development and Capabilities 16 (1): 47-68.

Kembhavi, G., and S. Wirz. 2009. Engaging adolescents with disabilities in research. ALTER European Journal of Disability 3: 286-296.

Kolltveit, S., I.I. Lange-Nielsen, A.A. Thabet, A. Dyregrov, S. Pallesen, T.B. Johnsen, and J.C. Laberg. 2012. Risk factors for PTSD, anxiety, and depression among adolescents in Gaza. Journal of Traumatic Stress 25 (2): 164-170.

Kuper, H., L.M. Banks, K. Blanchet, and M. Walsham. 2019. Social protection for people with disabilities in Africa and Asia: A review of programmes for low- and middle-income countries. Oxford Development Studies 47 (1): 97-112.

Landsdown, G. 2005. The evolving capacities of the child. Innocenti Insights No. 11. Geneva: UNICEF.

Mains, D. 2012. Hope is cut: Youth, unemployment and the future in urban Ethiopia, 2012. Philadelphia: Temple University Press.

Manning, S.M., P. Johnson, and J. Acker-Verney. 2016. Uneasy intersections: Critical understandings of gender and disability in global development. Third World Thematics: A TWQ Journal 1 (3): 292-306. 
McCarthy, K., M. Brady, and K. Hallman. 2016. Investing when it counts: Reviewing the evidence and charting a course of research and action for very young adolescents. New York: Population Council.

McKinnon, B., G. Gariépy, M. Sentenac, and F.J. Elgar. 2016. Adolescent suicidal behaviours in 32 low- and middle-income countries. Bulletin of the World Health Organization 94: 340-350F.

Mekonnen, M., S. Hannu, L. Elina, and K. Matti. 2015. Socio-emotional problems experienced by deaf and hard of hearing students in Ethiopia. Deafness \& Education International 17 (3): $155-162$.

Misunas, C., C.M. Gastón, and C. Cappa. 2019. Child marriage among boys in high-prevalence countries: An analysis of sexual and reproductive health outcomes. BMC International Health and Human Rights 19 (25): 1-16.

Nanda, P., N. Datta, and P. Das. 2014. Impact of conditional cash transfers on girls' education. New Delhi: ICRW.

Nelson, C.A., Z.A. Bhutta, N. Burke Harris, A. Danese, and M. Samara. 2020. Adversity in childhood is linked to mental and physical health throughout life. BMJ 371: m3048. https://doi.org/10. 1136/bmj.m3048.

Nussbaum, M. 1997. Capabilities and human rights. Fordham Law Review 66 (2): 273.

Nussbaum, M. 2000. Women and human development: The capabilities approach. Cambridge: Cambridge University Press.

Parsons, J., J. Edmeades, A. Kes, S. Petroni, M. Sexton, and Q. Wodon. 2015. Economic impacts of child marriage: A review of the literature. The Review of Faith \& International Affairs 13 (3): 12-22.

Patton, G.C., C. Coffey, S.M. Sawyer, R.M. Viner, D.M. Haller, K. Bose, T. Vos, J. Ferguson, and C.D. Mathers. 2009. Global patterns of mortality in young people: A systematic analysis of population health data. The Lancet 374 (9693): 881-892.

Patton, G.C., S.M. Sawyer, J.S. Santelli, et al. 2016. Our future: A Lancet commission on adolescent health and wellbeing. The Lancet. 387 (10036): 2423-2478.

Pinheiro, P.S. 2006. World report on violence against children. Geneva: United Nations.

Pogge, T., and M. Sengupta. 2016. Assessing the Sustainable Development Goals from a human rights perspective. Journal of International and Comparative Social Policy 32 (2): 83-97.

Porter, G. 2011. 'I think a woman who travels a lot is befriending other men and that's why she travels': Mobility constraints and their implications for rural women and girl children in subSaharan Africa. Gender, Place and Culture 18 (1): 65-81.

Presler-Marshall, E. 2018. Adolescent boys in Jordan: The state of the evidence. London: Gender and Adolescence: Global Evidence.

Presler-Marshall, E., N. Jones, and K. Bani Odeh. 2019. 'Even though I am blind, I am still human!' The neglect of adolescents with disabilities' human rights in conflict-affected contexts. Child Indicators Research 13: 513-531.

Presler-Marshall, E., N. Jones, S. Alheiwidi, S. Youssef, B. Abu Hamad, K. Bani Odeh, S. Baird, E. Oakley, S. Guglielmi, and A. Małachowska, 2020. Through their eyes: Exploring the complex drivers of child marriage in humanitarian contexts. Report. London: Gender and Adolescence: Global Evidence.

Prout, A., and A. James. 1990. A new paradigm for the sociology of childhood? Provenance, promise and problems. In Constructing and reconstructing childhood, ed. A. James and A. Prout, 7-33. London: Falmer.

Renner, S., L. Bok, N. Igloi, and N. Linouet. 2018. What does it mean to leave no one behind? A UNDP discussion paper and framework for implementation. New York: United Nations Development Programme. www.undp.org/content/undp/en/home/librarypage/poverty-reduction/what-does-it-mean-toleave-no-one-behind-.html.

Robles, O., and A. Spindler. 2016 Getting it right when it matters the most: Adolescents in emergencies. Paper presented at conference on Adolescence, Youth and Gender: Building Knowledge for Change, 8-9 September, Oxford.

Samman, E. 2017. 10 Things to know about 'leave no one behind.' Briefing Paper. London: Overseas Development Institute.

Samman, E., P. Lucci, J. Hagen-Zanker, H. Bhatkal, A.T. Simunovic, S. Nicolai, E. Stuart, and C. Caron. 2018. SDG progress: Fragility, crisis and leaving no one behind. Report. London: Overseas Development Institute and International Rescue Committee.

Sen, A.K. 1984. Commodities and capabilities. Oxford: Oxford University Press.

Sen, A.K. 1993. Capability and wellbeing. In The quality of life, ed. M. Nussbaum and A.K. Sen, 30-53. Oxford: Clarendon Press. 
Sen, A.K. 1999. Development as freedom. Oxford: Oxford University Press.

Shove, E. 2010. Beyond the ABC: Climate change policy and theories of social change. Environment and Planning A Economy and Space 42 (6): 1273-1285.

Siddiqi, M., and M. Greene. 2019. Mapping the field: A systematic scoping study of child marriage research, 2013-2019. Washington, DC: GreeneWorks.

Sommers, M. 2011. Governance, security and culture: Assessing Africa's youth bulge. International Journal of Conflict and Violence 5 (2): 292-303.

Steinberg, L., and K. Monahan. 2007. Age differences in resistance to peer influence. Developmental Psychology 43 (6): 1531-1543.

Stewart, F. 2005. Groups and capabilities. Journal of Human Development 6 (2): 185-204.

Stewart, F., and S. Deneulin. 2002. Amartya Sen's contribution to development thinking. Studies in Comparative International Development 37 (2): 61-70.

Sukarieh, M., and S. Tannock. 2008. In the best interests of youth or neoliberalism? The World Bank and the New Global Youth Empowerment Project. Journal of Youth Studies 11 (3): 301-312. https://doi.org/ 10.1080/13676260801946431.

Tefera, B., P. Pereznieto, and G. Emirie. 2013. Transforming the lives of girls and young women: Case study, Ethiopia. London: Overseas Development Institute.

Trani, J.-F., P. Bakhshi, and M. Biggeri. 2011. Rethinking children's disabilities through a capabilities lens: A framework for analysis and policy implications. In Children and the capability approach, ed. M. Biggeri, J. Ballet, and J. Comim. London: Palgrave.

UN Secretary General. 2014. Policies and programmes involving youth: Report of the Secretary General. Report. New York: UN.

UN Working Group on the issue of discrimination against women in law and in practice. 2017. Women's autonomy, equality and reproductive health in International Human Rights: Between recognition, backlash and regressive trends. Geneva: United Nations Human Rights Special Procedures. Office of the High Commissioner for Human Rights.

UNESCO. 2015. EFA Global Monitoring Report 2015. Education for All 2000-2015: Achievements and challenges. Paris: UNESCO.

UNESCO. 2018. Achieving gender equality in education: Don't forget the boys. Policy Paper 35. Paris: UNESCO.

UNESCO. 2019. The intersections between education, migration and displacement are not gender-neutral. Global Monitoring Report. Paris: UNESCO.

UNESCO. 2020. Inclusion and Education: All means all. Global Education Monitoring Report. Paris: UNESCO.

UNESCO Institute of Statistics. 2018. One in five children, adolescents and youth is out of school. Fact Sheet No. 48. Montreal and Paris: UNESCO Institute for Statistics.

UNHCR. 2018. Her turn: It's time to make refugee girls' education a priority. UN Factsheet. www.unhcr. org/herturn.

UNICEF. 1989. Convention on the rights of the child. New York: United Nations. www.unicef.org.uk/Docum ents/Publication-pdfs/UNCRC_PRESS200910web.pdf.

UNICEF. 2014a. A statistical snapshot of violence against adolescent girls. Factsheet. New York: UNICEF.

UNICEF. 2014b. A study on early marriage in Jordan. Report. New York: UNICEF.

UNICEF. 2017. Is every child counted? Status of data for children in the SDGs. Factsheet. New York: UNICEF.

Unterhalter, E., C. Yates, H. Makinda, and A. North. 2012. Blaming the poor: constructions of marginality and poverty in the Kenyan education sector. Compare: A Journal of Comparative and International Education 42 (2): 213-233. https://doi.org/10.1080/03057925.2012.652386.

Vaughan, R.P. 2016. Gender equality and education in the sustainable development goals. Background paper prepared for 2016 Global Education Monitoring Report, Education for People and Planet: Creating Sustainable Futures For All. Paris: UNESCO.

Wanjiru, J. 2018. Inclusive education for internally displaced children in Kenya: Children's perceptions of their learning and development needs in post-conflict schooling. International Journal of Child Care and Education Policy 12 (1): 1.

Watson, C. 2015. Understanding changing social norms and practices around girls' education and marriage: Lessons learned and emerging issues from year 2 of a multi-country field study. London: Overseas Development Institute.

White, S.C., and S.A. Choudhury. 2007. The politics of child participation in international development: The dilemma of agency. The European Journal of Development Research 19 (4): 529-550. 
WHO. 2002. Gender and mental health. Geneva: WHO.

WHO. 2014. Health for the world's adolescents: A second chance in the second decade of life. Geneva: WHO.

WHO. 2015. Adolescent health. WHO Factsheet. Geneva: WHO. www.who.int/topics/adolescent_health/en.

WHO. 2018. Disability and health. Factsheet. Geneva: WHO. www.who.int/en/news-room/fact-sheets/detail/ disability-and-health.

Young, I.M. 2009. The gendered cycle of vulnerability in the less developed world. In Toward a humanist justice: The political philosophy of susan moller okin, ed. D. Satz and R. Reich. Oxford: Oxford University Press.

Publisher's Note Springer Nature remains neutral with regard to jurisdictional claims in published maps and institutional affiliations. 